\title{
Potential use of Coffee Bean Parchment as Substrate for Soilless Tomato (Solanum Lycopersicum L.) Cultivation in Gabon
}

\author{
Assani Soulaïmana ${ }^{1}$, Kassi Koffi Fernand Jean-Martial ${ }^{2}$, \\ Bomisso Edson Lezin' ${ }^{2}$, N'dri Konan Lazare', \\ Assa Rebecca Epse Yao ${ }^{3}$, Ake Séverin ${ }^{2}$
}

\author{
${ }^{1}$ HORTA, Horticulture, Arboriculture and Agronomy Company, Gabon \\ ${ }^{2}$ Laboratory of Plant Physiology, UFR (Faculty) of Biosciences, University Félix Houphouët-Boigny 22 B.P.582, \\ Côte d'Ivoire \\ ${ }^{3}$ Laboratory of Biochemistry and Food Science, UFR Biosciences, University Félix Houphouët-Boigny 22 B.P.582, \\ Côte d'Ivoire
}

\begin{abstract}
This work proposes to promote coffee bean parchment as substrate of soilless tomato plant cultivation by looking for the adequate particle-size distribution and the optimal dose of calcium hypochlorite to be used for disinfecting the substrate. Substrates with different particle-size distribution $(2.8,2.25$ and $1.85 \mathrm{~mm}$ in diameter) were subjected to direct (porosity, specific humidity, $\mathrm{pH}$, organic matter, mineral content, carbon content) and then indirect morphological characterization after disinfection or not with different doses of calcium hypochlorite (10; $20 ; 30 ; 40 \mathrm{~g} / \mathrm{l})$, based on germination and height growth estimates of the plants produced. The results showed that the physicochemical properties of substrates S1 (raw bean parchment) and S2 (bean parchment screened with 2.85 mm-mesh sieve) were close to those of the reference substrate (FC), which was coir. With respect to calciumhypochlorite disinfected culture substrates, the substrates ( $\mathrm{S} 1$ : raw bean parchment $+10 \mathrm{~g} / \mathrm{l}$ of calcium hypochlorite) and (S2: bean parchment screened with $2.85 \mathrm{~mm}$-mesh sieve $+10 \mathrm{~g} / \mathrm{l}$ calcium hypochlorite) were the best regarding the combination of physicochemical and vegetative parameters of tomato plants and could be recommended as substrate for substituting coir (FC).
\end{abstract}

Keywords: Coffee Bean Parchment, Physicochemical Characteristics, Soilless Cultivation, Tomato

\begin{abstract}
Introduction
Tomato (Solanum lycopersicum L.) is an annual plant belonging to the family Solanaceae (Brazeau, 2015). It is mainly grown for its fruits rich in mineral salts and vitamins (N'Zi et al., 2000). Its cultivation is practiced in more than 170 countries and in different climates thanks to the soilless cultivation technique (Chougourou et al., 2012). This technique currently represents an important alternative that helps optimize agricultural production factors while improving yields (Bernier, 2015). It covers more than 772,940 ha in Asia and 201,570 ha in Europe (Urban and Urban, 2010, M'Sadak and Ben M'Barek, 2015a). In Africa, soilless cultivation is very poorly developed; it is practiced over a surface area of 30,740 ha (Boulard, 2008). The cost of production due to the import of substrates, in this case coir, is one of the major constraints to the development of this cropping practice. The simultaneous requirement of high productivity and profitability of soilless cultivated crops is a challenge for the survival of this production system. It therefore becomes imperative to search for other types of substrates locally, which are inexpensive, available and easy to use. Many
\end{abstract}

studies try to substitute partially or completely these substrates by promoting agricultural by-products (Van Der Gaag et al., 2007). Thus, a study carried out in Gabon showed that coffee bean parchment, which is a waste resulting from fruit hulling, inexpensive, can be used as a potential alternative to coir. However, since the particle-size distribution of the substrate is a factor influencing plant growth (Richards et al., 1986, M'Sadak), the adequate particle size remains a major concern in the use of coffee bean parchment in tomato cultivation. Thus, the level of substrate disinfection is also a major challenge in the search for the alternative to coir. The selection of the disinfectant and the dose to be applied are also important criteria for the popularization of coffee bean parchment as substrate, especially since the metham sodium used for disinfection in Gabon is under recall because of its adverse effects on health and the environment (Anonymous, 2018).

This study aims at determining the physical properties and chemical characteristics of different coffee bean parchment-based substrates at different

This article is published under the terms of the Creative Commons Attribution License 4.0 Author(s) retain the copyright of this article. Publication rights with Alkhaer Publications. Published at: http://www.ijsciences.com/pub/issue/2019-09/

DOI: 10.18483/ijSci.2178; Online ISSN: 2305-3925; Print ISSN: 2410-4477 
particle gradients. And then at assessing the response of tomato seeds and seedlings vis-à-vis the best substrates disinfected with different doses of calcium hypochlorite in order to offer tomato producers a competitive alternative in soilless cultivation.

\section{I - MATERIAL AND METHODS \\ I.1 - Material}

\section{I.1.1-Plant Material}

The tomato (Lycopersicum esculentum) seeds used in this study were of the Yaara variety. It is a tomato variety that tolerates hot and humid equatorial and tropical climates (Anonymous, 2017).

\section{I.1.2 - Substrates}

Coffee bean parchment, derived from the hulling of the robusta variety grown in Franceville (Gabon), was used to form four (4) substrates:

- S1, unscreened coffee bean parchment;

- S2, screened coffee bean parchment, with particles $\leq 2.80 \mathrm{~mm}$;

- S3, screened coffee bean parchment, with particles $\leq 2.25 \mathrm{~mm}$;

- S4, screened coffee bean parchment, with particles $\leq 1,85 \mathrm{~mm}$.

- FC, coir-based substrate. This substrate served as control in the physicochemical analysis of coffee bean parchment-based substrates. It was bought at SIGMA.

\section{I.1.3-Disinfection product}

Calcium hypochlorite with different doses (10, 20, 30 and $40 \mathrm{~g} / \mathrm{L}$ ) was used for the disinfection trial of coffee bean parchment particles.

\section{I.2 - Methods}

\section{I.2.1 - Assessment of the physical characteristics of substrates.}

I.2.1.1- Porosities. In order to determine the retention or flow capacities of substrates at different sizes of coffee bean parchment particles, three different types of porosity were assessed. These included the total porosity (total space not occupied by the substrate), aeration porosity (spaces occupied by air in the substrate) and water-holding porosity (spaces occupied by substrate-held water)

The porosities of the different substrates were determined using a cell tray. For this purpose, the drainage holes of three wells of the cell tray were blocked and filled with water. This water was then collected in a graduated cylinder to determine the volume (VT) of each cell. The empty cells were blocked at the drain holes and then filled with coffee bean parchment particle substrates of different sizes. A volume of water (VA) was slowly poured onto the substrates contained in the cells until total saturation. The waterlogged substrate was allowed to stand for 1 $\mathrm{h}$. The water drain holes were then opened so as to collect drainage water (VR) for $10 \mathrm{~min}$. The different types of porosity were then determined (Pt: total porosity, Pa: aeration porosity and Pr: water-holding porosity) according to the following formulas:

$\mathrm{Pt}(\%)=(\mathrm{VA} / \mathrm{VT}) \times 100$;

$\mathrm{Pa}(\%)=(\mathrm{VR} / \mathrm{VT}) \times 100$;

$\operatorname{Pr}(\%)=\mathrm{Pt}-\mathrm{Pa}$.

With:

VT: Total volume of the cell

VA: Volume of water needed to saturate the substrate VR: Volume of water collected by drainage of the substrate

\section{I.2.1.2- Specific humidity.}

The determination of the substrate specific humidity was made according to the standardized method (ISO $11465,1993)$ modified and adapted to our material. Thus, $5 \mathrm{~g}$ of each substrate were removed and put in an oven at $70^{\circ} \mathrm{C}$ for $48 \mathrm{~h}$. The Specific Humidity (HS) of the substrate was determined by applying the following formula:

$H S(\%) \frac{P_{1}-P_{2}}{P 1} \times 100$

With: P1: Wet weight before drying in the oven; P2: Dry weight after drying in the oven.

\section{I.2.2 - Determination of substrate chemical characteristics}

I.2.2.1 - pH In order to determine the $\mathrm{pH}$ of the substrates, 3 samples of $5 \mathrm{~g}$ of each substrate were each placed in $20 \mathrm{ml}$ of distilled water and then allowed to stand for 30 minutes. The solutions obtained were filtered using a filter paper and the $\mathrm{pH}$ values of the filtrate determined by the electronic method at the $\mathrm{pH}$ meter.

\section{I.2.2.2 - Organic matter (MO)}

The organic matter content of the different substrates was determined by the method of loss on ignition or L.O.I. modified and adapted to our equipment. The average organic matter content of the substrate was determined from the following formula:

MO $(\%)=$

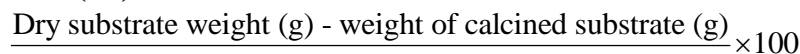
Dry substrate weight $(\mathrm{g})$

\subsubsection{3 - Carbon content determination}

The organic carbon content was determined from the proportion of organic matter in the substrates following the relationship below.

$\operatorname{Corg}(\%)=\frac{\text { MO }(\%)-1,5}{1,4}$

\section{I.2.2.4 - $\mathrm{C} / \mathrm{N}$ ratio}

The $\mathrm{C} / \mathrm{N}$ ratio which expresses the rate of mineralization was obtained by applying the formula: $\mathrm{C} / \mathrm{N}=\operatorname{Corg}(\%) / \mathrm{N}(\%)$ 


\section{I.2.2.5- Mineral content determination}

Mineral contents such as Calcium (Ca), Potassium (K) and Sodium (Na) were determined by flame photometer. Magnesium (Mg) content of the substrates was determined by the atomic absorption spectrometer. Phosphorus (P) content was determined by the colorimetric method at $400 \mathrm{~nm}$ wavelength, thanks to its yellow coloring with the vanadomolybdic reagent. Total nitrogen determination was carried out by the Kjeldahl method.

\section{I.2.3- Assessment of the residual effects of calcium} hypochlorite doses on tomato plant germination and growth parameters

The assessment of the residual effects of calcium hypochlorite doses was made on substrates with characteristics similar to coir ones.

\section{I.2.3.1- Substrate preparation}

The coffee bean parchment was disinfected with calcium hypochlorite at different doses $(10 \mathrm{~g} / \mathrm{l}, 20 \mathrm{~g} / \mathrm{l}$, $30 \mathrm{~g} / \mathrm{l}$ and $40 \mathrm{~g} / \mathrm{l})$ and then rinsed under continuous water jet for $1 \mathrm{~min}$. In total, five (5) treatments were assessed. These included:

- T0, substrate having received no dose of calcium hypochlorite (coir);

- T1, substrate disinfected with $10 \mathrm{~g} / \mathrm{l}$ of calcium hypochlorite;

- T2, substrate disinfected with $20 \mathrm{~g} / \mathrm{l}$ of calcium hypochlorite;

- T3, substrate disinfected with $30 \mathrm{~g} / \mathrm{l}$ of calcium hypochlorite;

- T4, substrate disinfected with $40 \mathrm{~g} / \mathrm{l}$ of calcium hypochlorite.

\section{I.2.3.2- Experimental design}

The split plot design with three repetitions was used to assess the residual effect of treatments with calcium hypochlorite. Five treatment modalities and two modalities of coffee bean parchment-based substrate were assessed. Twenty (20) tomato seeds were sown for each substrate modality and each treatment modality with calcium hypochlorite. The total number of seeds per block was 200 and 40 for each sub-block.

\section{I.2.3.3- Germination rate determination}

The seeds were germinated on substrates S1 and S2 treated with different concentrations of calcium hypochlorite. Germination monitoring lasted 21 days. The seed germination rate was calculated according to the following formula:

$\mathbf{G}(\%)=$

Number of sprouted seeds per treatment

Total number of seeds sown per treatment

\section{I.2.3.4- Growth parameters}

The height growth parameters and the number of living leaves of the plants was retained to study the residual effect calcium hypochlorite substrate treatments on tomato plant growth. A total of 40 plants were used per treatment (substrate-calcium hypochlorite dose) in a split-plot design with three repetitions, that is, 400 plants for the entire experiment. The height of the plants was determined using a tape measure and the number of leaves by count. Plant growth monitoring lasted 1 month.

\section{I.2.4 - Statistical analysis of the data}

All collected data were subjected to statistical tests using STATISCA Version 7.1 software. A one-way analysis of variance was used to assess the physicochemical characteristics of the substrates and the effects of calcium hypochlorite substrate treatments on tomato seedling germination and growth. The hypothesis of equality of averages was assessed at $\alpha$ risk $=5 \%$. In case of rejection of this hypothesis, the Newman-Keuls multiple comparison test at 5\% threshold was used to classify the averages into homogeneous groups. Principal component analysis (PCA) and hierarchical classification were performed using the XL STAT software to characterize the substrates (screen underflow) according to physicochemical characteristics.

\section{II - Results \\ II.1 - Physical characteristics of substrates \\ II.1.1- Porosity}

The analysis of average values of the different types of porosities (total, water-holding and aeration) of the substrates shows a significant difference between the different types of substrates (Figure 1). Indeed, all the coffee bean parchment-based substrates showed higher water-holding than the control (FC). Substrate S4 showed the highest water-holding capacity $(85.040 \%)$ and the lowest capacity was obtained with the control $(62.28 \%)$. Regarding total porosity, the coffee bean parchment-based substrates gave higher total porosity rates than the control. The highest total porosity value was obtained with substrate S3 (97.14\%) for a rate of $91.23 \%$ in the control. The percentages of aeration porosity ranged from $9.23 \%$ to $29.61 \%$ and revealed a significant difference between the substrates $(\mathrm{P}<0.05)$. Substrates $\mathrm{S} 1$ and S2 showed aeration rates that were not significantly different from that of the control $(\mathrm{S} 1=29.61 \%, \mathrm{~S} 2=$ $28.51 \%$, Control $=28.95 \%$ ). Substrate S4 showed the lowest aeration porosity rate $(9.23 \%)$.

\section{II.1.2- Specific humidity}

The studies for determining specific humidity showed variability in the substrates (Figure 2). It varied from $15.10 \%$ to $31.06 \%$. Substrate S1 showed the lowest specific humidity value $(15.1 \%)$. The highest value $(31.06 \%)$ was observed in the control.

II.2 - Chemical characteristics of substrates

The chemical characterization studies carried out 
showed variability in the composition of the different substrates (Table I). Coffee bean parchment-based substrates showed a different $\mathrm{pH}$ depending on the size of the particles. Substrates S1, S3 and S4 gave $\mathrm{pH}$ close to neutrality, $7.1 ; 7$ and 6.9 , respectively. The $\mathrm{pH}$ of substrate $\mathrm{S} 2$ (6.3) was not significantly different coir one (6.2). Non-screened coffee bean parchment-based substrates (S1) and medium-sized particle ones (S2 and S3) showed statistically identical conductivity levels. These three different ways of structuring coffee bean parchment proved to be richer in mineral elements, especially potassium $(1.55 \%, 1.7 \%, 1.68 \%)$, calcium $(0.54 \% ; 0.56 \%$, $0.44 \%)$ and magnesium $(0.32 \%, 0.5 \%, 0.35 \%)$. The coir-based substrate and the coffee bean parchment fine particle-based one were not significantly different and favored the lowest conductivity coefficients and mineral proportions. However, the coir-based substrate (FC) was characterized by high contents of organic matter $(98.73 \%)$ and organic carbon $(69.44 \%)$. Concerning the mineralization of the nitrogen contained in the substrates, illustrated by the $\mathrm{C} / \mathrm{N}$ ratio, it was faster respectively in the nonscreened coffee bean parchment (S1), in the coir (FC) and in the coffee bean parchment with particles less than or equal to $2.80 \mathrm{~mm}$. It should be noted that the coir-based substrate (FC) was richer in nitrogen $(\mathrm{N}=$ $0.97 \%)$ than coffee bean parchment-based substrates S1 $(0.9 \%), \mathrm{S} 2(0.87 \%), \mathrm{S} 3(0.66 \%)$ and S4 (0.66\%).

The Principal Component Analysis (PCA) made it possible to screen the different substrates assessed on the basis of physicochemical parameters (Figure 3). With a contribution of $84.31 \%$, axes 1 and 2 faithfully show the variability contained in the data. Axis 1 opposes substrates S1, S2 and FC to substrates S3 and S4.

- FC is characterized by high values of $\mathrm{Pa}, \mathrm{Mo}, \mathrm{Na}$, and $\mathrm{N}$.

- S3 and S4 are characterized by high values of P, Pr, $\mathrm{C} / \mathrm{N}$ and $\mathrm{pH}$.

- S1 and S2 are characterized by average values of the parameters correlated to axis $1(\mathrm{Mo}, \mathrm{Na}, \mathrm{Pa}$, $\mathrm{P}, \mathrm{Pr}, \mathrm{C} / \mathrm{N}$ and $\mathrm{pH}$ )

A clustering dendogram of substrates based on physicochemical characteristics and at the dissimilarity distance of 200 allowed to determine two groups of substrates (Figure 4). The first group consisted of substrates S3 and S4 and the second group of substrates FC, S1 and S2.

\section{II.3- Effect of calcium hypochlorite treatments on germination and growth parameters}

The treatment of substrates S1 and S2 with different doses of calcium hypochlorite had no significant influence on tomato seed germination rate (Figure 5). The growth parameters concerned the height of plants and the number of leaves generated.

Plant height growth was statistically different depending on the calcium hypochlorite dose used for disinfection (Figure 6). The reduction in plant height was proportional to the increase in calcium hypochlorite dose. The highest growths were obtained with the two substrates (S1 and S2) at the dose of $10 \mathrm{~g} / \mathrm{l}$ of calcium hypochlorite. Regarding the average number of leaves generated, the increasing dose of hypochlorite significantly reduced this growth parameter (Figure 7). The highest average number of leaves on both substrates was obtained at the dose of $10 \mathrm{~g} / \mathrm{l}$ of calcium hypochlorite.

\section{Iii- Discussion}

This work consisted in the physicochemical characterization of coffee bean parchment-based substrates and the assessment of the residual effect of calcium hypochlorite doses on tomato plant germination, leaf generation and height.

The analysis of the results relating to the physicochemical characteristics of coffee bean parchment showed that they vary depending on granulometry. The principal component analysis showed that regarding chemical properties, coir stands out with high organic matter (MO), nitrogen (N) and sodium (Na) contents. Concerning substrates $\mathrm{S} 3$ and $\mathrm{S} 4$, they had high $\mathrm{C} / \mathrm{N}$ ratios and potassium (K) contents. In contrast, these substrates opposed to coir by their low organic matter (MO), nitrogen $(\mathrm{N})$ and sodium (Na) contents. As for substrates $\mathrm{S} 1$ and $\mathrm{S} 2$, they recorded average values in organic matter (MO), sodium (Na), electrical conductivity (CE), phosphorus $(\mathrm{P}), \mathrm{C} / \mathrm{N}$ ratio and $\mathrm{pH}$. Moreover, the hierarchical classification through the dendrogram showed that the physicochemical properties of substrates $\mathrm{S} 1$ and $\mathrm{S} 2$ are close to coir ones. In addition, the $\mathrm{pH}$ of coffee bean parchment-based substrates was conducive to good uptake of nutrients by the roots (Anonymous, 2017). However, the high organic matter content of the substrates and their very high $\mathrm{C} / \mathrm{N}$ ratios show that access to the minerals contained in the substrates is difficult to the plants because of the slow mineralization (Bernal, 1998). However, this should be taken into account in the preparation of the nutrient solution. Furthermore, Ammari et al., 2007 stated that the physical properties of a substrate are more important than the chemical properties because they influence water absorption and mineral elements (Landi, 1990). Thus, coffee bean parchment-based substrates would be better assessed on the basis of their physical characteristics.

With regard to physical properties, the results showed that substrates $\mathrm{S} 1$ and $\mathrm{S} 2$ are close to coir regarding their total, aeration and water-holding porosity. In contrast, substrates S3 and S4 oppose coir with an aeration below the standard recommended by Morel et al. (2000). These results would be justified by the size of the particles that make up these substrates. Indeed, substrates S3 and S4 calibrated with $1.85 \mathrm{~mm}$ 
and $2.25 \mathrm{~mm}$-mesh respectively are dominated by finer particles than raw coffee bean parchment (S1) and coffee bean parchment screened with $2.85-\mathrm{mm}$ mesh (S2). And according to M'Sadak et al. (2016), a substrate composed mainly of fine particles holds more water but is poorly aerated. Such substrates can lead to the death of root hairs by asphyxiation caused by lack of oxygen (Kozlowski, 1997) as confirmed by the works of Boudrault (2010). This author observed the death of white spruce root hairs after 24 $\mathrm{H}$ in saturated water conditions. Thus $1.85 \mathrm{~mm}$ and $2.25 \mathrm{~mm}$-mesh are not recommended for the substrate calibration in tomato cultivation. According to Richards et al. (1986), substrate in tomato cultivation requires substrates rich in coarse particles.

The residual effect of calcium hypochlorite on tomato germination and growth was assessed by disinfection of substrates S1 and S2 with different doses. Germination results showed no significant difference between the treatments (substrate + dose). The doses of calcium hypochlorite did not affect seed germination capacity. These results would be justified by the fact that the threshold of seed sensitivity to calcium hypochlorite is not reached at the different doses assessed. Our results corroborate those of Nzengue et al., (2016), who worked on coffee bean parchment disinfected with different doses of sodium hypochlorite. These authors have shown that the doses of $10 \mathrm{~g} / \mathrm{l}, 20 \mathrm{~g} / \mathrm{l}, 30 \mathrm{~g} / \mathrm{l}$ and 40 $\mathrm{g} / \mathrm{l}$ of sodium hypochlorite do not affect tomato germination.

Regarding tomato plant growth, the analysis of the results showed that the average height and average number of leaves of the plants varied significantly from one treatment to another. The average height and average number of leaves of the plants produced on the substrates disinfected with $10 \mathrm{~g} / 1$ were significantly close to those of the control plants. Beyond $10 \mathrm{~g} / \mathrm{l}$, the growth of the plants decreases when the dose increases. These results could be explained by disorders that might cause a high content of $\mathrm{Ca}^{2+}$ ions and hypochlorites $\left(\mathrm{ClO}^{-}\right)$ stemming from calcium hypochlorite dissolution. This high content in coffee bean parchment can lead to a competition of these ions with the absorption of other ions essential for the growth of the plants. According to Tahraoui (2015), calcium competes with the absorption of other cations, such as magnesium $(\mathrm{Mg})$ and potassium $(\mathrm{K})$, which can cause a deficiency in these elements and create disruption of many physiological mechanisms leading to growth disorders.

Moreover, the high $\mathrm{Ca}^{2+}$ and $\mathrm{ClO}^{-}$content may be subject to osmotic potential assessment that may inhibit water absorption at the root level (R'him et al., 2013). Indeed, plant growth is controlled by cell division and expansion. Difficulties in water absorption by the roots results in the decrease of cell division number, and therefore the decrease in plant growth (Alioua et al., 2016).

\section{Conclusion And Outlook}

This study was devoted to direct and indirect assessment of disinfected coffee bean parchmentbased substrates for soilless tomato plant production. The physicochemical analyses and the monitoring of germination and growth parameters of the plants cultivated on various substrates with variable granulometry, made it possible mainly to show that the physicochemical properties of substrates S1 (raw coffee bean parchment) and S2 (coffee bean parchment screened with $2.85 \mathrm{~mm}$-mesh) are close to those of the reference substrate (FC), which is coir. Concerning substrates disinfected with calcium hypochlorite, substrates (S1: raw coffee bean parchment $+10 \mathrm{~g} / \mathrm{l}$ of calcium hypochlorite) and (S2: coffee bean parchment screened with $2.85 \mathrm{~mm}$-mesh $+10 \mathrm{~g} /$ calcium hypochlorite) are the best in terms of physicochemical parameters and vegetative parameters of the plants.

At the end of this study, the raw coffee bean parchment or the one with $2.85 \mathrm{~mm}$ granulometry disinfected with calcium hypochlorite $(10 \mathrm{~g} / \mathrm{l})$ could partially constitute an alternative substrate to coir for soilless tomato production.

\section{References}

1. Alioua H. et Bouzenad I., 2016. Influence du stress salin sur la germination, la croissance et le rendement de quelques populations locales du niébér (Vigna unguiculata subsp. Unguiculata (L) Walp.) Mémoire en vue de l'obtention de master en agronomie ENSA El Harrach : 111p.

2. Ammari Y., -Mohammed S., Lamhamedi A., El Abidine Z. et Akrimi N., 2007. Production et croissance des plants résineux dans différents substrats à base de compost dans une pépinière forestière moderne en Tunisie. Rev. For. Fr. LIX, 4: $339-359$.

3. Anonyme, 2007. www.freshfelt.org (consulté le 23/07/2019)

4. Anonyme, 2017. Comprendre pour agir avec le livre vert. Agrisymbiose, France, 15p.

5. Anonyme.,

https://fr.wikipedia.org/wiki/M\%C3\%A9tham_sodium (consulté le 23/07/2019)

6. Bernal M.P., Paredes C., Sanchez M.M.A. et Cegarra J., 1998. Maturity and stability parameters of composts prepared with a wide range of organic wastes. Bioresour. Technol., $63: 91-99$

7. Bernier P., 2015. Vers la construction d'un discours critique de l'agriculture urbaine commerciale en serres sur les toits. Mémoire présenté comme exigence partielle de la maîtrise en sociologie. Université du Québec Montréal, 183p,

8. Boudrault S., 2010. Effets des propriétés physiques et chimiques des substrats sur la croissance et le développement de plants d'épinette blanche en récipient après une saison de culture. Mémoire de maitre des sciences, option Sciences de l'Agriculture et de l'Alimentation, Université Laval Québec, $79 \mathrm{p}$.

9. Boulard T., 2008. Peut-on concilier production sous serre et développement durable ? Serres horticoles et énergie. Acte de colloque, Brest-France, 37 p.

10. Chougourou D. C., Agbaka A., Adjakpa J. B., Koutchika E. R., Kponhinto U. G. et Adjalian E. J. N., 2012. Inventaire préliminaire de l'entomofaune des champs de tomates (Lycopersicon esculentum Mill.) dans la Commune de 
Djakotomey au Bénin. Int. J. Biol. Chem. Sci., 6 (4) : 1798 1804.

11. Kozlowski, T. T., 1997. Responses of woody plants to flooding and salinity. Tree physiology monograph 1:1-29

12. Landis T. D., 1990. Growing media. In: Containers and growing media. Washington, DC: U. S. Depart. Of Agri., Forest Serv, 674 (2): 41-85

13. M'Sadak Y et Tayachi L., 2014.Valorisation agronomique hors sol de la biométhanisation industrielle avicole en Tunisie. Rev. DesEner. Renouv., 17 (3) : 447 - 464

14. M'Sadak Y., EL Amri A., Majdoub R. et EL Ghorball L., 2016. Comportements physique et hydrique des substrats de culture destinés aux pépinières forestières modernes (sahel tunisien). Algerian j. of arid environ.6(1): 96-107.

15. Morel P., Poncet P. et Rivière L.M., 2000. Les supports de culture horticoles : Les matériaux complémentaires et alternatifs à la tourbe, Éditions INRA, $84 \mathrm{p}$.

16. N'Zi J. C., Kouamé C., Fondio L. et Djidji H., 2000.Interaction génotype-environnement

17. NZengueE.,Iponga M D.,M'SadakY.,Owona A .G .S.,ZingaKoumba C.R., Assani S., M'batchi B., et Mavoungou J.F., 2016. Production des plants de Tomate (Lycopersicon esculentum) sur substrats de culture à base de parche de café à différents gradients de désinfection dans une pépinière maraîchère hors sol au Gabon. Inter $J$ of Innov and Sci Res.26 (1) : 83- 94
18. R'him T., Tlili I., Hnan I., Ilahy R., Benali A et Jebari H., 2013. Effet de stress salin sur le comportement physiologique et métabolique de 3 variétés de piment (Capsicum annum L.). J. Appl. Biosci. 66 : 50605069.

19. Richards D., Lane M. et Beardsell D. V., 1986. The influence of particle-size distribution in pinebark:sand:brown coal potting mixes on water supply, aeration and plant grow. Sci. Horticult., 29: 1-14

20. sur les performances de la tomate (Lycopersiconesculentum) Agro. Afric.,12 (2): 51 - 61.

21. Tahraoui S., 2015. Effet des sels solubles sur la production de la biomasse et l'absorption des éléments minéraux chez l'orge (Hordium vulgare) et le blé dur (Triticum durum). Mémoire de Magister. Université Mohamed Khider- Biskra, Algérie. $140 \mathrm{p}$

22. Urban L. et Urban I., 2010. La production sous serre, tome 1 : la gestion du climat (2 ème édition). Édition Tec et Doc, Paris, $356 \mathrm{p}$.

23. Van Der Gaag D.J., Van Noort F.R., Stapel-Cuijpers L.H.M., DeKreij C., Termorshuizen A.J., Van Rijn E., Zmora-Nahum SH., et Chen Y., 2007. The use of green waste compost in peat-based potting mixtures: Fertilization and suppressiveness against soilborne diseases, Scientia Horticulturae, 114: 289-297.

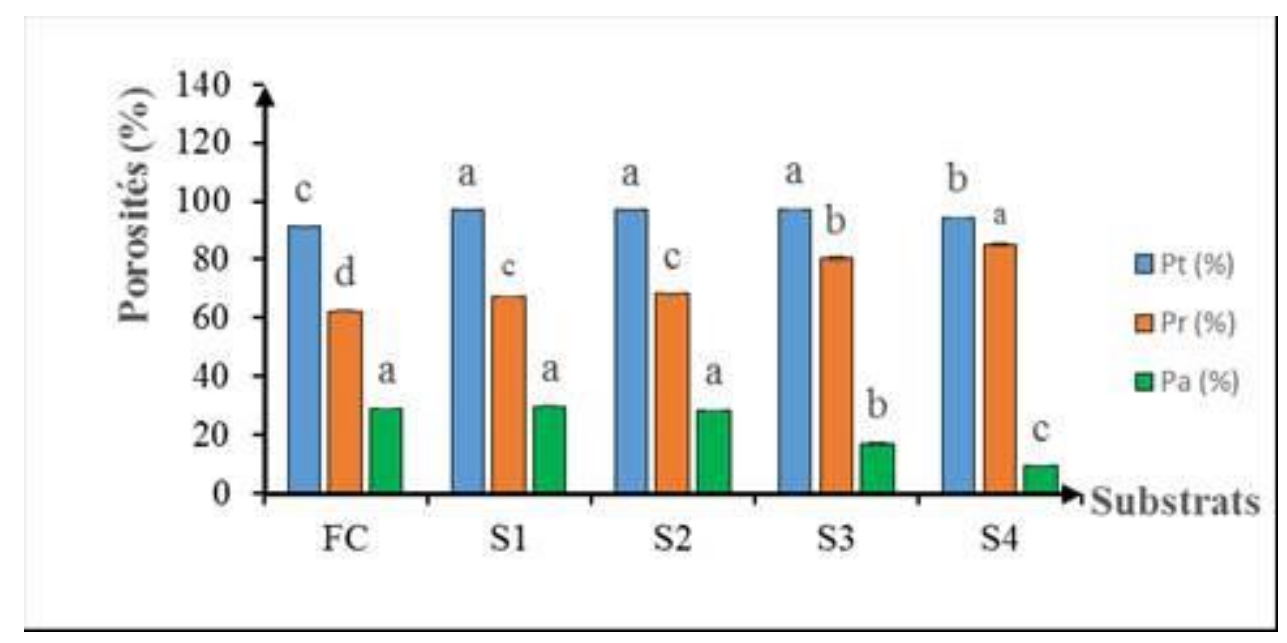

Figure 1: Porosity rates of different coffee bean parchment and coir-based substrates

Pt: Total porosity, Pr: Water-holding porosity, Pa: Aeration porosity

* The averages assigned with the same letter are not significantly different according to the Newman-Keuls test at $5 \%$ threshold. 


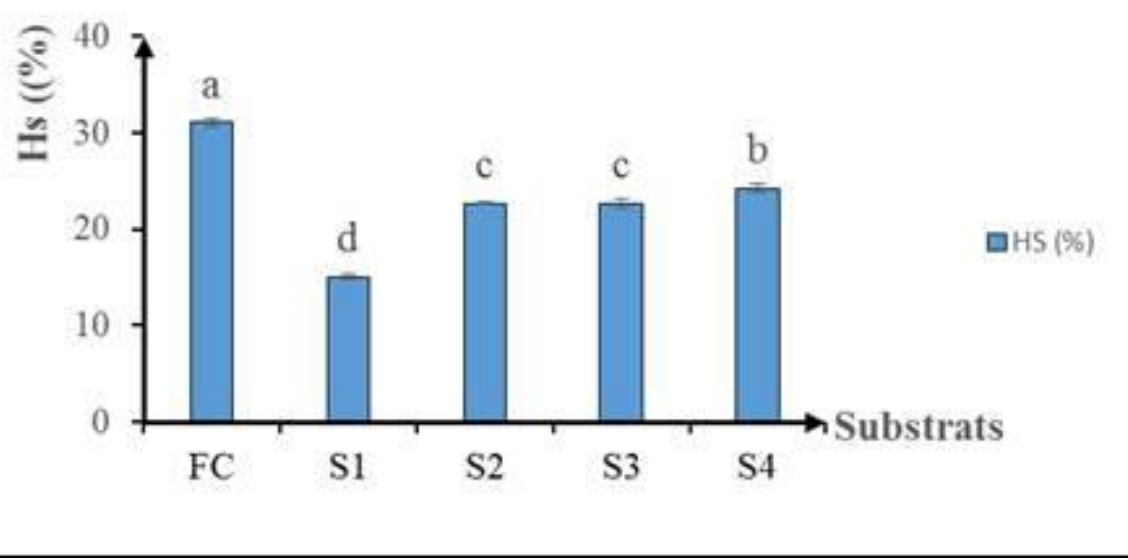

Figure 2: Specific humidity rate (Hs) of composite substrates

* The averages followed by the same letter are not significantly different according to the Newman-Keuls test at $5 \%$ threshold.

Table I: Chemical parameters of the different coffee bean parchment-based substrates tested

\begin{tabular}{lllllll}
\hline Substrates & FC & \multicolumn{2}{c}{ S1 } & \multicolumn{2}{c}{ S2 } & S3 \\
\hline $\mathrm{pH}$ & $6.2^{\mathrm{b}}$ & $7.1^{\mathrm{a}}$ & $6.3^{\mathrm{b}}$ & $7^{\mathrm{a}}$ & $6.9^{\mathrm{a}}$ & \\
$\mathrm{CE}(\mathrm{mS} / \mathrm{cm})$ & $0.59^{\mathrm{b}}$ & $0.86^{\mathrm{a}}$ & $0.85^{\mathrm{a}}$ & $0.79^{\mathrm{a}}$ & $0.56^{\mathrm{b}}$ & \\
$\mathrm{MO}(\%)$ & $98.73^{\mathrm{a}}$ & $91^{\mathrm{b}}$ & $91.93^{\mathrm{b}}$ & $91.86^{\mathrm{b}}$ & $88.06^{\mathrm{c}}$ & \\
$\mathrm{Corg}(\%)$ & $69.44^{\mathrm{a}}$ & $63.92^{\mathrm{b}}$ & $64.59^{\mathrm{b}}$ & $64.54^{\mathrm{b}}$ & $61.83^{\mathrm{c}}$ & \\
$\mathrm{N}(\%)$ & $0.97^{\mathrm{a}}$ & $0.90^{\mathrm{b}}$ & $0.87^{\mathrm{b}}$ & $0.66^{\mathrm{d}}$ & $0.66^{\mathrm{d}}$ & \\
$\mathrm{C} / \mathrm{N}$ & $71.59^{\mathrm{b}}$ & $70.77^{\mathrm{b}}$ & $73.97^{\mathrm{b}}$ & $97.33^{\mathrm{a}}$ & $95.22^{\mathrm{a}}$ \\
$\mathrm{P}(\%)$ & $2.18^{\mathrm{d}}$ & $3.26^{\mathrm{c}}$ & $3.81^{\mathrm{ab}}$ & $3.65^{\mathrm{b}}$ & $4.05^{\mathrm{a}}$ \\
$\mathrm{K}(\%)$ & $0.21^{\mathrm{d}}$ & $1.55^{\mathrm{b}}$ & $1.70^{\mathrm{a}}$ & $1.68^{\mathrm{a}}$ & $1.50^{\mathrm{c}}$ \\
$\mathrm{Ca}(\%)$ & $0.39^{\mathrm{c}}$ & $0.54^{\mathrm{a}}$ & $0.56^{\mathrm{a}}$ & $0.44^{\mathrm{b}}$ & $0.36^{\mathrm{d}}$ & \\
$\mathrm{Mg}$ & $0.25^{\mathrm{c}}$ & $0.32^{\mathrm{b}}$ & $0.50^{\mathrm{a}}$ & $0.35^{\mathrm{b}} 0.27^{\mathrm{c}}$ & \\
$\mathrm{Na}(\%)$ & $0.02^{\mathrm{a}}$ & $0.015^{\mathrm{bc}}$ & $0.014^{\mathrm{bc}}$ & $0.017^{\mathrm{b}}$ & $0.010^{\mathrm{c}}$ &
\end{tabular}

* The averages assigned with the same letter are not significantly different according to the Newman-Keuls test at $5 \%$ threshold 


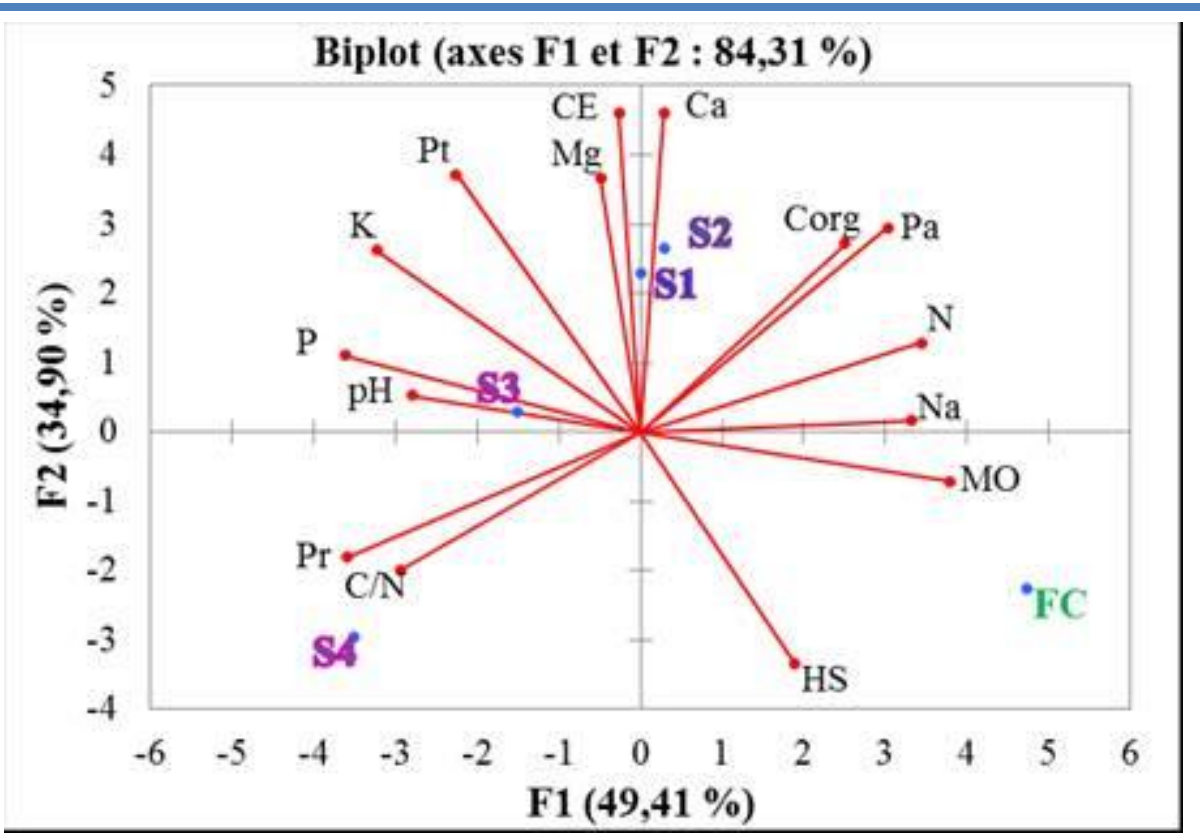

Figure 3: Distribution of substrates depending on their physicochemical characteristics according to axis 1 and 2 of a Principal Component Analysis

\section{Dendrog amme}

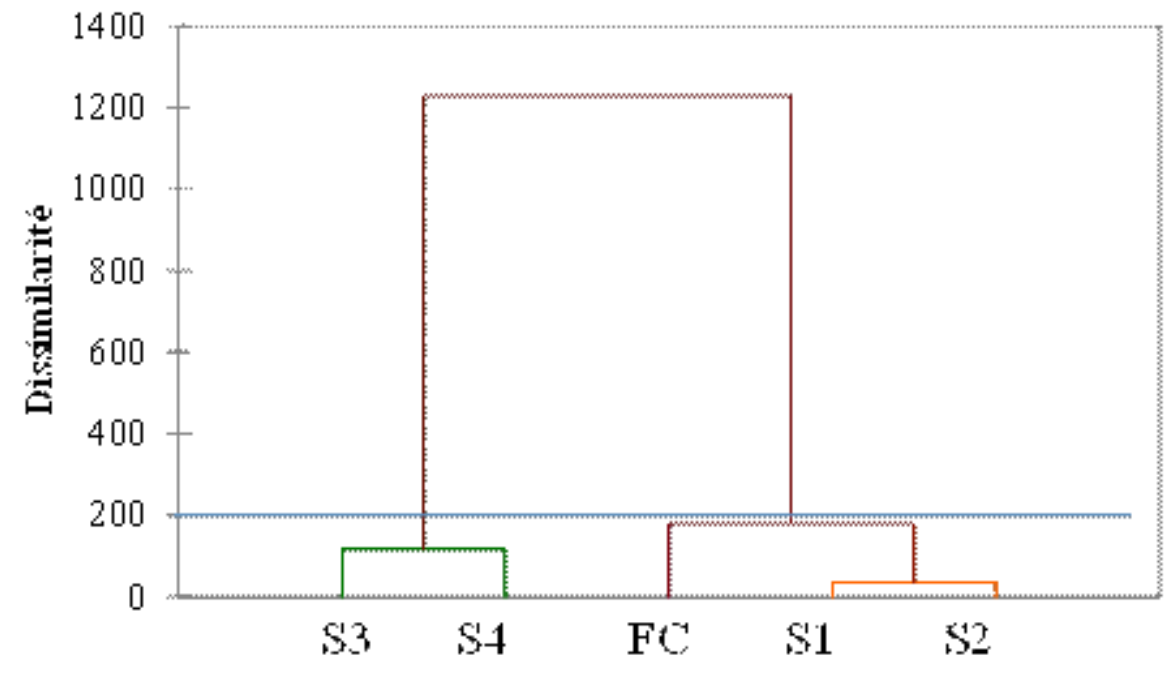

Figure 4: Substrate grouping basing on physicochemical characteristics 


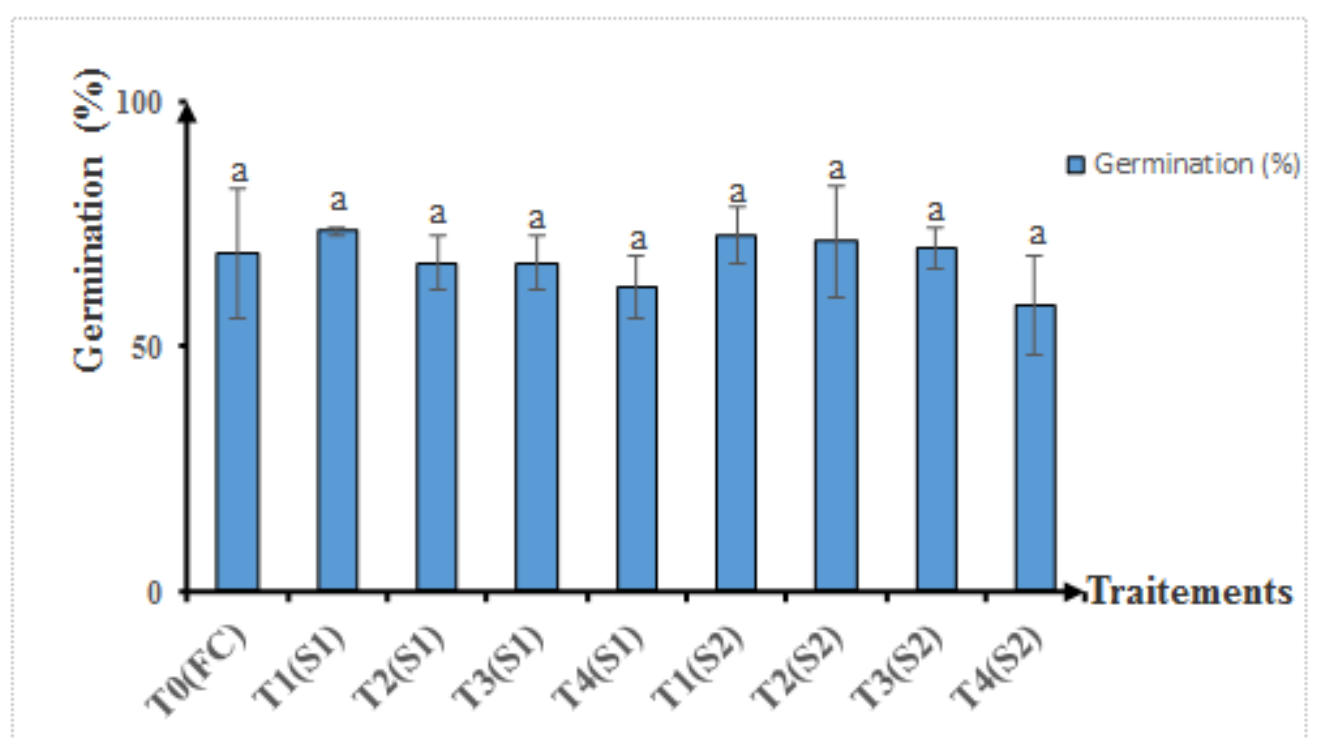

Figure 5: tomato germination rate on substrates $\mathrm{S} 1$ and $\mathrm{S} 2$ depending on the doses applied for disinfection

* The averages assigned with the same letter are not significantly different according to the Newman-Keuls test at $5 \%$ threshold

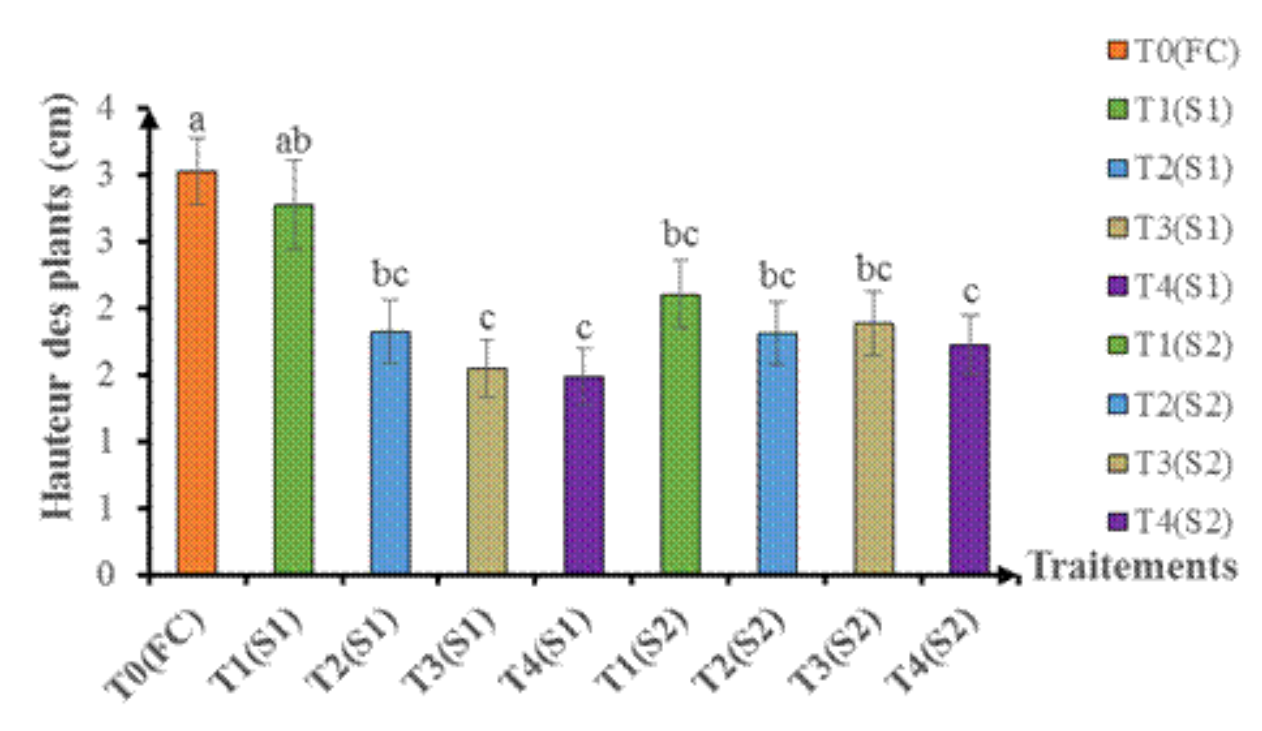

Figure 6: Height of tomato plants on substrates S1 and S2 depending on the doses applied for disinfection

* The averages assigned with the same letter are not significantly different according to the Newman-Keuls test at $5 \%$ threshold 


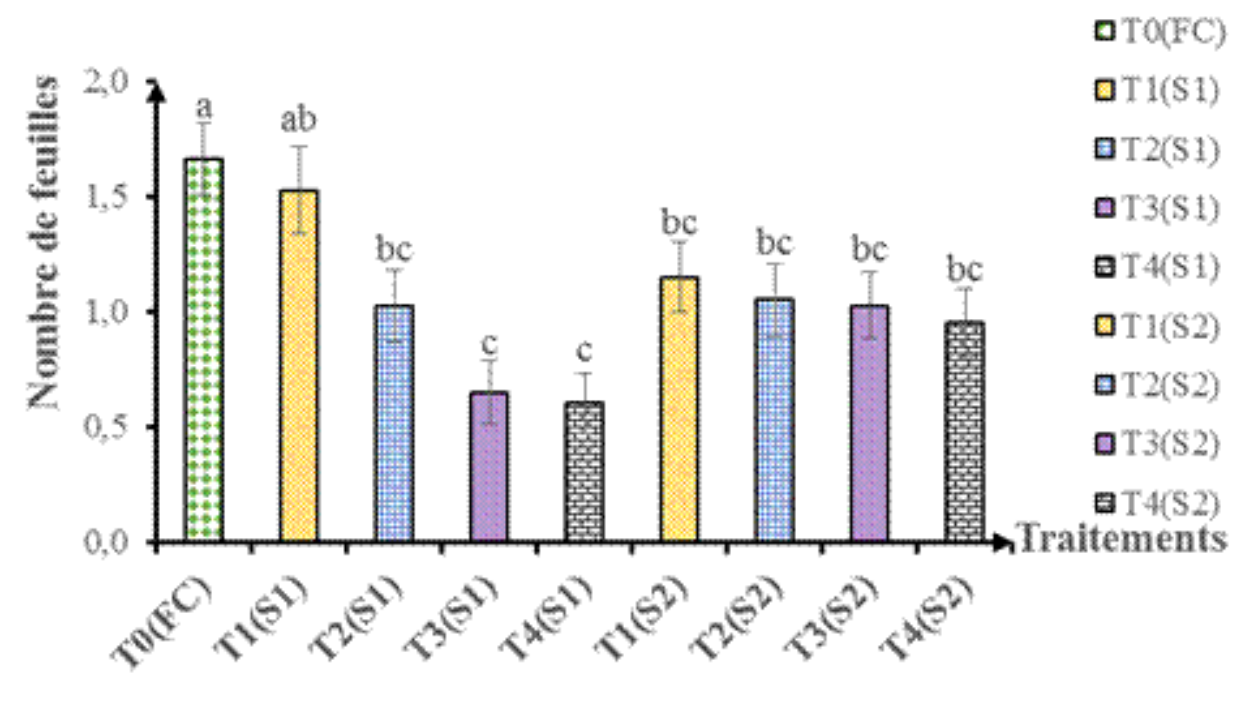

Figure 7: Average number of leaves per plant on substrates S1 and S2 as a function of the doses applied for disinfection

* The averages assigned with the same letter are not significantly different according to the Newman-Keuls test at $5 \%$ threshold 